\title{
Wymagania dotyczące przeglądów stanu technicznego budynków - studium przypadku
}

\author{
Krystyna Urbańska1, Pawel Urbański² \\ ${ }^{1}$ Zakład Mechaniki Budowli, Wydział Budownictwa, Architektury i Inżynierii Środowiska, \\ Uniwersytet Zielonogórski,e-mail: k.urbanska@ib.uz.zgora.pl \\ ${ }^{2}$ Zakład Technologii Budownictwa, Geotechniki i Geodezji, Wydziat Budownictwa, Architektury \\ i Inżynierii Środowiska, Uniwersytet Zielonogórski, e-mail: p.urbanski@ib.uz.zgora.pl
}

\begin{abstract}
Streszczenie: Celem artykułu jest zwrócenie uwagi na jakość wykonywanych w ostatnim czasie okresowych przeglądów stanu technicznego budynków oraz zasygnalizowanie zarządcom budynków potrzeby sprawdzania zawartości otrzymywanych opracowań. Zwłaszcza w przypadku znacznej ilości zleceń przyjmowanych w jednym terminie. Ocenę rzetelności sporządzanych okresowych przeglądów stanu technicznego przedstawiono na przykładzie budynku wielorodzinnego zlokalizowanego w Zielonej Górze.
\end{abstract}

Słowa kluczowe: przeglądy stanu technicznego budynków, planowanie remontów.

\section{Wprowadzenie}

Systematyczne szacowanie stopnia zużycia technicznego budynków powinno stanowić jeden z wyjściowych punktów do kompleksowego zarządzania substancją mieszkaniową. Wstępne prawidłowe i szczegółowe rozeznanie stanu technicznego budynków może pozwolić na racjonalne planowanie remontów bieżących i kapitalnych, począwszy od ich wielkości poprzez specyfikę, a skończywszy na ekonomicznej opłacalności ich wykonania.

Jednakże warunki, które są w stanie umożliwić realizację powyższych kryteriów dotyczą: rzetelnego wykonywania przeglądów stanu technicznego budynków, prawidłowego skonstruowania i wypełnienia protokołów z przeprowadzonych okresowych (rocznych lub pięcioletnich) kontroli, konieczności ich weryfikacji przez podmioty zlecające ich realizację. W ostatnich latach wśród zarządców odpowiadających za utrzymanie dużej grupy budynków, należy zauważyć tendencję prowadzącą do przedkładania ilości (konieczności wykonania przeglądu uwarunkowanego [1], [2], [3]) nad jakością otrzymywanych opracowań. Należy jednak podkreślić fakt, że w wielu przypadkach czynnikiem decydującym o takim podejściu jest czynnik ekonomiczny.

\section{Wybrane uwarunkowania prawne dotyczące przeglądów stanu technicznego}

Analiza rzetelności wykonywanych przeglądów oraz powstałych w ich wyniku opracowań w postaci protokołów musi opierać się na wcześniejszej analizie uwarunkowań prawnych, które powinny stanowić wyznacznik dla prawidłowości ich wykonania. Poniżej przedstawiono wybrane wymagania dotyczące prawidłowości realizacji przeglądów.

Zgodnie z [1] Art. 61. Obiekt budowlany wraz ze związanymi z nim urządzeniami budowlanymi należy, biorąc pod uwagę przewidywany okres użytkowania, projektować, budować 
i użytkować zgodnie z przepisami, w tym techniczno-budowlanymi, obowiązującymi Polskimi Normami oraz zasadami wiedzy technicznej, w sposób umożliwiający właściwe utrzymanie stanu technicznego oraz zapewniając spełnienie wymagań podstawowych dotyczących:

- bezpieczeństwa konstrukcji;

- bezpieczeństwa użytkowania;

- bezpieczeństwa pożarowego;

- ochrony przed hałasem i drganiami;

- odpowiednich warunków higienicznych i zdrowotnych oraz ochrony środowiska;

- oszczędności energii i odpowiedniej izolacyjności przegród.

W myśl art. 61 właściciel lub zarządca powinien utrzymywać obiekt w należytym stanie technicznym i estetycznym, nie dopuszczając do nadmiernego pogorszenia jego właściwości użytkowych i sprawności technicznej. Należyty stan techniczny to taki, w którym wszystkie elementy, instalacje i urządzenia zachowują pełną sprawność techniczną oraz odpowiadają wymaganiom prawa, czyli przepisom techniczno-budowlanym i Polskich Norm.

Za istotne dla trwałości można uznać wymagania dotyczące sprawdzania stanu technicznej sprawności elementów budynku mieszkalnego i jego instalacji narażonych na szkodliwe wpływy atmosferyczne i niszczące działania czynników występujących podczas użytkowania obiektu.

Według Art. 62. 1. Obiekty budowlane powinny być w czasie ich użytkowania poddawane przez właściciela lub zarządcę kontroli:

1) okresowej, co najmniej raz w roku, polegającej na sprawdzeniu stanu technicznego:

a) elementów budynku, budowli i instalacji narażonych na szkodliwe wpływy atmosferyczne i niszczące działania czynników występujących podczas użytkowania obiektu;

b) instalacji i urządzeń służących ochronie środowiska;

c) instalacji gazowych oraz przewodów kominowych (dymowych, spalinowych i wentylacyjnych);

2) okresowej, co najmniej raz na 5 lat, polegającej na sprawdzeniu stanu technicznego i przydatności do użytkowania obiektu budowlanego, estetyki obiektu budowlanego oraz jego otoczenia; kontrolą tą powinno być objęte również badanie instalacji elektrycznej i piorunochronnej w zakresie stanu sprawności połączeń, osprzętu, zabezpieczeń i środków ochrony od porażeń, oporności izolacji przewodów oraz uziemień instalacji i aparatów;

3) okresowej w zakresie, o którym mowa w pkt 1, co najmniej dwa razy w roku, w terminach do 31 maja oraz do 30 listopada, w przypadku budynków o powierzchni zabudowy przekraczającej $2000 \mathrm{~m}^{2}$ oraz innych obiektów budowlanych o powierzchni dachu przekraczającej $1000 \mathrm{~m}^{2}$; osoba dokonująca kontroli jest obowiązana bezzwłocznie pisemnie zawiadomić właściwy organ o przeprowadzonej kontroli;

4) bezpiecznego użytkowania obiektu każdorazowo w przypadku wystąpienia okoliczności, o których mowa w art. 61 pkt 2.

Analizując [2] należy zwrócić uwagę na następujące wymagania:

Budynek z pomieszczeniami przeznaczonymi na pobyt ludzi powinien być wznoszony poza zasięgiem zagrożeń i uciążliwości, przy czym dopuszcza się wznoszenie budynków w tym zasięgu pod warunkiem zastosowania środków technicznych zmniejszających uciążliwości poniżej poziomu ustalonego w tych przepisach bądź zwiększających odporność budynku na te zagrożenia i uciążliwości, jeżeli nie jest to sprzeczne z warunkami ustalonymi dla obszarów ograniczonego użytkowania. 
Do uciążliwości tych zalicza się:

- szkodliwe promieniowanie i oddziaływanie pól elektromagnetycznych;

- hałas i drgania (wibracje);

- zanieczyszczenie powietrza;

- zanieczyszczenie gruntu i wód;

- powodzie i zalewanie wodami opadowymi;

- szkody spowodowane d ziałalnością górniczą.

Zgodnie z $\$ 203$ budynki i urządzenia z nimi związane powinny być projektowane i wykonywane w taki sposób, aby obciążenia mogące na nie działać, zarówno w trakcie budowy jak i użytkowania, nie prowadziły do:

- zniszczenia całości lub części budynku;

- przemieszczeń i odkształceń o niedopuszczalnej wielkości;

- uszkodzenia części budynków, połączeń lub zainstalowanego wyposażenia w wyniku znacznych przemieszczeń elementów konstrukcji;

- zniszczenia na skutek wypadku, w stopniu nieproporcjonalnym do jego przyczyny.

Konstrukcja powinna spełniać warunki zapewniające nie przekroczenia stanów granicznych nośności oraz stanów nośności przydatności do użytkowania w żadnym jej elemencie. Stany graniczne nośności uważa się za przekroczone, jeżeli konstrukcja powoduje zagrożenie bezpieczeństwa ludzi znajdujących się w budynku oraz w jego pobliżu, a także zniszczenie wyposażenia lub przechowywanego mienia.

Natomiast za przekroczone stany graniczne przydatności do użytkowania uważa się:

- lokalne uszkodzenia, w tym również rysy, które mogą ujemnie wpływać na przydatność użytkową, trwałość i wygląd konstrukcji lub jej części, a także przyległych do niej niekonstrukcyjnych elementów;

- odkształcenia lub przemieszczenia ujemnie wpływające na wygląd konstrukcji i jej przydatność użytkową, włączając w to również funkcjonowanie maszyn i urządzeń, oraz uszkodzenia części niekonstrukcyjnych lub elementów wykończenia;

- drgania dokuczliwe dla ludzi lub powodujące uszkodzenia budynku, jego wyposażenia oraz przechowywanych przedmiotów, a także ograniczające jego użytkowanie zgodne z przeznaczeniem.

Rozporządzenie [3] narzuca wymagania dotyczące prawidłowości użytkowania budynków oraz określa zasady sporządzania protokołów przeglądu. Najważniejsze paragrafy to:

Rozporządzenie to określa warunki, które mają zapewnić:

- utrzymanie stanu technicznego budynku na poziomie zapewniającym bezpieczeństwo ludzi i mienia w okresie jego użytkowania;

- ochronę zdrowia i życia ludzi w pomieszczeniach budynku;

- utrzymanie wymaganego stanu estetycznego budynku, a w przypadku wpisania budynku do rejestru zabytków - zachowanie jego wartości podlegających ochronie konserwatorskiej;

- zgodne z przeznaczeniem użytkowanie budynku i znajdujących się w nim pomieszczeń oraz urządzeń związanych z budynkiem;

- możliwość racjonalizacji zużycia wody i nośników energii zgodnie z wymaganiami użytkowników lokali, lecz w sposób nie naruszający interesów osób trzecich i nie powodujący pogorszenia właściwości użytkowych i technicznych budynku i związanych z nim urządzeń.

W celu właściwego użytkowania budynku należy przeprowadzać kontrole okresowe najlepiej w porze wiosennej. Osoba przeprowadzająca kontrolę okresową budynku powinna przed 
jej rozpoczęciem zapoznać się z protokołami z poprzednich kontroli, z protokołami odbioru robót remontowych wykonanych w budynku w okresie od poprzedniej kontroli, zgłoszeniami użytkowników lokali dotyczącymi usterek, wad, uszkodzeń lub zniszczeń elementów budynku.

Protokoły sporządzane w wyniku kontroli okresowych mają zawierać określenie:

- stanu technicznego elementów budynku objętych kontrolą;

- rozmiarów zużycia lub uszkodzenia elementów;

- zakresu robót remontowych i kolejności ich wykonywania;

- metod i środków użytkowania elementów budynku narażonych na szkodliwe działanie wpływów atmosferycznych i niszczące działanie innych czynników;

- zakresu nie wykonanych robót remontowych zaleconych do realizacji w protokolach z poprzednich kontroli okresowych.

Niezależnie od kontroli okresowych właściciel budynku może przeprowadzać przeglądy robocze mające na celu określenie stanu przygotowania budynku, urządzeń i instalacji do użytkowania w okresie zimowym.

Okresowej kontroli podlegają elementy budynku narażone na szkodliwe wpływy atmosferyczne i niszczące działania czynników występujących podczas użytkowania, których uszkodzenia mogą powodować zagrożenie dla:

- bezpieczeństwa osób;

- środowiska;

- konstrukcji budynku.

W toku kontroli szczegółowym sprawdzeniem należy objąć stan techniczny:

- zewnętrznych warstw przegród zewnętrznych (warstwa fakturowa), elementów ścian zewnętrznych (attyki, filary, gzymsy), balustrad, loggii i balkonów;

- urządzeń zamocowanych do ścian i dachu budynku;

- elementów odwodnienia budynku oraz obróbek blacharskich;

- pokryć dachowych;

- instalacji centralnego ogrzewania i ciepłej wody użytkowej;

- urządzeń stanowiących zabezpieczenie przeciwpożarowe budynku;

- elementów instalacji kanalizacyjnej odprowadzających ścieki z budynku;

- przejść przyłączy instalacyjnych przez ściany budynku;

- estetykę budynku i jego otoczenia.

Dane zawarte w protokołach kontroli stanowią podstawę do sporządzenia zestawienia robót remontowych budynku, które zostały podzielone na:

- roboty konserwacyjne;

- naprawy bieżące;

- naprawy główne.

Na podstawie tego zestawienia dokonuje się sporządzenia planu robót remontowych. Przy decyzji o remoncie, pierwszeństwo mają tu prace mające na celu:

- eliminację zagrożenia bezpieczeństwa użytkowników lokali i osób trzecich;

- zabezpieczenie przeciwpożarowe budynku;

- spełnienie wymagań ochrony środowiska;

- zachowanie zapobiegawczego charakteru remontu. 


\section{Jakość wykonywanych przeglądów [4] w odniesieniu do przepi- sów i rzeczywistego stanu technicznego}

W punkcie tym dokonano oceny jakości wykonanych w ostatnich latach dla zarządców budynków wielorodzinnych w Zielonej Górze, przeglądów stanu technicznego budynków. $\mathrm{Na}$ przykładzie wybranego jednego budynku z grupy obiektów [4], po przeprowadzeniu własnej wizji lokalnej, wskazano niedociągnięcia jakie miały miejsce w trakcie wykonania przeglądu oraz opracowywania protokołu.

Szczegółowy opis, zaobserwowanych w trakcie oględzin budynku, uchybień w protokole wraz z odwołaniami do dokumentacji fotograficznej sporządzonej przez autorów artykułu przedstawiono w Tab.1. Kolorem czerwonym opisano usterki, które nie znalazły się w protokole a wg autorów artykułu są niezbędne dla rzetelnego wykonania oceny.

Tabela 1. Wybrany protokół przeglądu budowlanego 5-cio letniego [4], Zgodnie z art. 62 ust.1, pkt 1 Prawa budowlanego z wyłączeniem instalacji gazowych i przewodów kominowych

Nazwa kontrolowanego obiektu: Budynek mieszkalny

Adres: Zielona Góra ul. $40 / 42 / 44 / 46$

Kod budynku:

Ocena elementów obiektu:

Lp. Nazwa Ocena stanu technicznego Opis stanu technicznego, uszkoelementu i przydatności do użytkowania

5 - dobry, 4 - zadowalający,

3 - niezadowalający, 2 - zły dzeń i rozmiaru zużycia
Stopień pilności usunięcia wskazanych usterek*
1 Fundamenty i ściany piwnic $4 / 3$

nie ustalono podnięcia ścian osłonowych, zwłasz- czas przeglądu cza w rejonie klatki 42 od strony frontowej które mogą być spowodowane osiadaniem lub złym stanem fundamentów. (błędna lokalizacja pęknięć - powinno być: zwłaszcza w rejonie klatki 46 od strony frontowej, patrz Fot. 1)

2 Ściany konstrukcyjne

4/3 (brak lokalizacji pęknięć, Fot. 1) nie ustalono podczas przeglądu

3 Zawilgocenie/zagrzybienie ścian zewnętrznych

4 Nie stwierdzono zawilgocenia nie ustalono pod(niezgodne ze stanem faktycz- czas przeglądu nym, patrz. Fot. 5)

4 Elementy ścian zewnętrznych: nadproża, gzymsy, attyki, filary

3/2 Zamoknięte i uszkodzone tynki II wskutek skorodowanych obróbek - wymienić obróbki (brak oceny gzymsów dachowych, brak sugestii do remontu tynków) 


\begin{tabular}{|c|c|c|c|c|}
\hline 6 & $\begin{array}{l}\text { Klatki schodowe: biegi, spo- } \\
\text { czniki, poręcze, tralki }\end{array}$ & 4 & $\begin{array}{l}\text { Nie stwierdzono uszkodzeń } \\
\text { konstrukcji klatek schodowych } \\
\text { (niezgodne ze stanem faktycz- } \\
\text { nym - patrz Fot. 2) }\end{array}$ & $\begin{array}{l}\text { nie ustalono pod- } \\
\text { czas przeglądu }\end{array}$ \\
\hline 7 & Dach/stropodach: konstrukcja & 4 & $\begin{array}{l}\text { Nie stwierdzono istotnych } \\
\text { uszkodzeń }\end{array}$ & \\
\hline 8 & Kominy części ponad dachem & $5 / 4$ & $\begin{array}{l}\text { Nie stwierdzono uszkodzeń (nie- } \\
\text { zgodne ze stanem faktycznym } \\
\text { - patrz Fot. } 3 \text { ) }\end{array}$ & $\begin{array}{l}\text { nie ustalono pod- } \\
\text { czas przeglądu }\end{array}$ \\
\hline 9 & Pokrycie dachu & $3 / 2$ & $\begin{array}{l}\text { Pokrycie naprawiane doraźnie } \\
\text { papa nierówna, miejscami od- } \\
\text { spojona od podłoża, miejscowe } \\
\text { nieszczelności-zaplanować } \\
\text { kompleksowy remont pokrycia } \\
\text { dachowego (niezgodne ze sta- } \\
\text { nem faktycznym - patrz Fot. } 4 \text { ) }\end{array}$ & II \\
\hline 10 & $\begin{array}{l}\text { Elementy odwodnienia dachu: } \\
\text { rynny, rury spustowe, kosze }\end{array}$ & $3 / 2$ & $\begin{array}{l}\text { Rynny i rury spustowe pokryte } \\
\text { korozją, nieszczelne-wskazana } \\
\text { wymiana (powinno być: Rynny } \\
\text { i rury spustowe skorodowane ... } \\
\text { patrz Fot. } 5,7 \text { ) }\end{array}$ & II \\
\hline 11 & $\begin{array}{l}\text { Inne obróbki blacharskie: } \\
\text { pokrycie ogniomurów, attyk } \\
\text { gzymsów, rury wentylacyjne) }\end{array}$ & $3 / 2$ & $\begin{array}{l}\text { Skorodowane obróbki dachowe, } \\
\text { balkonów, gzymsów-wykonać } \\
\text { nowe obróbki }\end{array}$ & II \\
\hline 12 & $\begin{array}{l}\text { Balkony, loggie, tarasy: kon- } \\
\text { strukcja, balustrady }\end{array}$ & $3 / 2$ & $\begin{array}{l}\text { Płyty balkonowe zamoknięte, } \\
\text { ubytki tynku i betonu, odsłonięte } \\
\text { korodujące zbrojenie, skoro- } \\
\text { dowane obróbki blacharskie - } \\
\text { wyremontować balkony }\end{array}$ & $\begin{array}{l}\text { III } \\
\text { (Rzeczywisty } \\
\text { stan to I - patrz } \\
\text { Fot. } 6,7,8)\end{array}$ \\
\hline 13 & $\begin{array}{l}\text { Urządzenia zamocowane do } \\
\text { ścian i dachu budynku }\end{array}$ & 4 & $\begin{array}{l}\text { Bez uwag (niezgodne ze stanem } \\
\text { faktycznym) }\end{array}$ & $\begin{array}{l}\text { nie ustalono pod- } \\
\text { czas przeglądu }\end{array}$ \\
\hline 14 & Opaska & $4 / 3$ & $\begin{array}{l}\text { Miejscowe nierówności i uszko- } \\
\text { dzenia-dokonać napraw }\end{array}$ & IV \\
\hline 15 & $\begin{array}{l}\text { Wejście: drzwi zewnętrzne, } \\
\text { oświetlenie wejścia, domofon, } \\
\text { stopnice, balustrady, estetyka }\end{array}$ & 3 & $\begin{array}{l}\text { Drzwi drewniane wyeksplo- } \\
\text { atowane (niezgodne ze stanem } \\
\text { faktycznym) }\end{array}$ & $\begin{array}{l}\text { IV Rzeczywisty } \\
\text { stan to II }\end{array}$ \\
\hline 16 & Stolarka okienna & $5 / 4$ & $\begin{array}{l}\text { Bez uwag (niezgodne ze stanem } \\
\text { faktycznym - patrz Fot. 9) }\end{array}$ & \\
\hline 17 & $\begin{array}{l}\text { Estetyka obiektu: tynki ze- } \\
\text { wnętrzne, malowanie, cokół }\end{array}$ & $4 / 3$ & $\begin{array}{l}\text { Elewacje zabrudzone, wyblakła } \\
\text { farba-wskazany remont elewacji } \\
\text { (niezgodne ze stanem faktycz- } \\
\text { nym - patrz Fot. } 10 \text { ) }\end{array}$ & $\begin{array}{l}\text { IV Rzeczywisty } \\
\text { stan to II }\end{array}$ \\
\hline 18 & $\begin{array}{l}\text { Podłogi i posadzki: klatka } \\
\text { schodowa, piwnice, strych }\end{array}$ & $4 / 3$ & $\begin{array}{l}\text { Nierówna posadzka betonowa } \\
\text { w piwnicy; w miarę możliwości } \\
\text { finansowych wykonać wylewkę } \\
\text { wyrównującą }\end{array}$ & IV \\
\hline 19 & $\begin{array}{l}\text { Tynki wewnętrzne: klatka scho- } \\
\text { dowa, piwnice }\end{array}$ & 4 & Bez uwag & \\
\hline
\end{tabular}




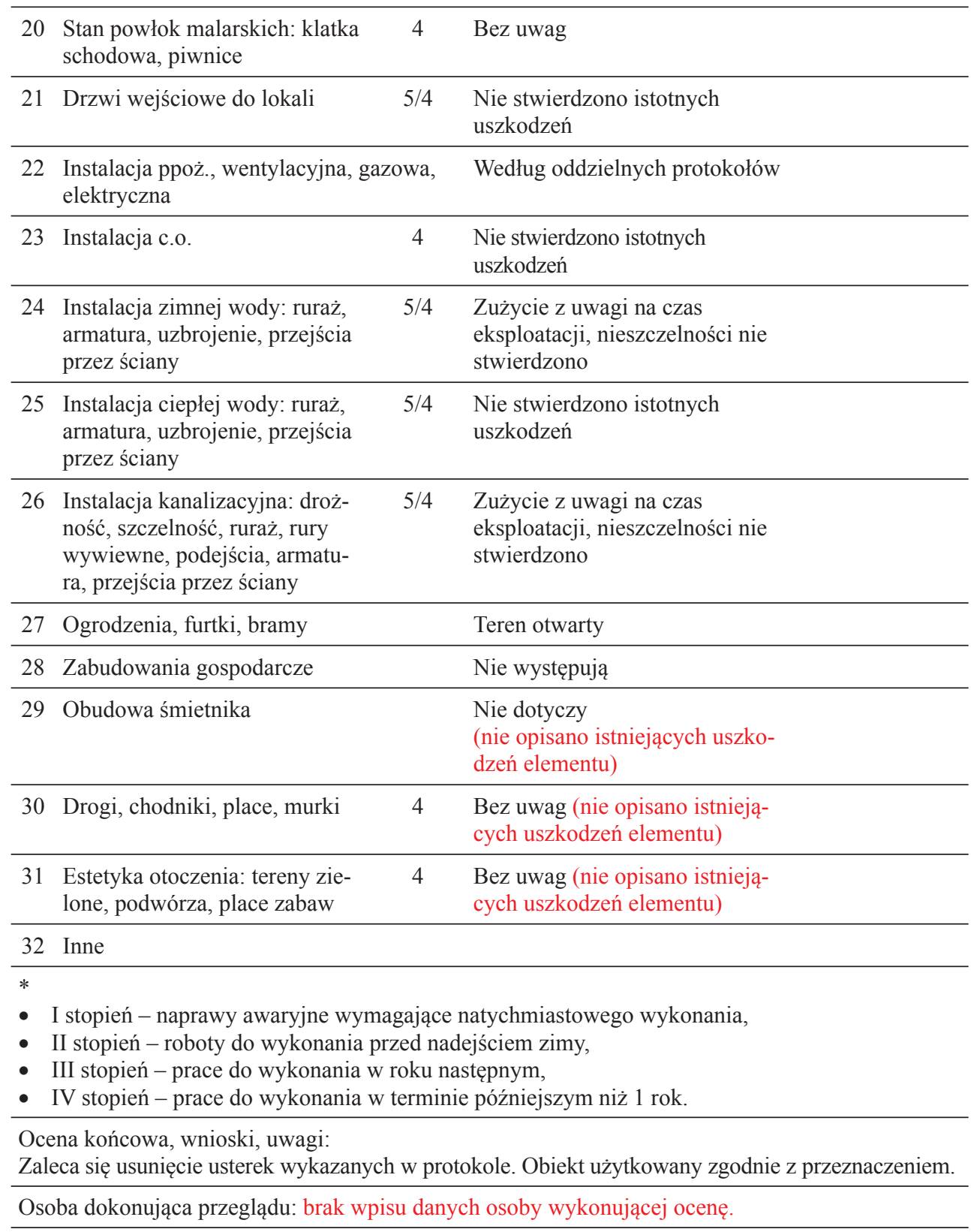

Zasadnicze niedociągnięcia wskazane w protokole związane były z przebiegiem przeglądu i w głównej mierze odnoszą się do:

- bardzo pobieżnej wizji lokalnej obiektów (w wielu przypadkach były to tylko oględziny zewnętrzne);

- braku wywiadów z mieszkańcami budynków;

- miejscami wątpliwej oceny stanu technicznego i wiążącej się z nią kwalifikacją elementu do grupy remontowej. 
Natomiast w kwestii dotyczącej opracowania protokołów należy zwrócić zasadniczą uwagę na brak odniesienia się do wcześniej przeprowadzanych przeglądów - zarówno w sferze sprawdzenia poprawności zrealizowanych zaleceń jak też w sferze porównania obecnego i ówczesnego stanu technicznego budynku. Protokół nie zawiera także danych osoby sporządzającej ocenę.

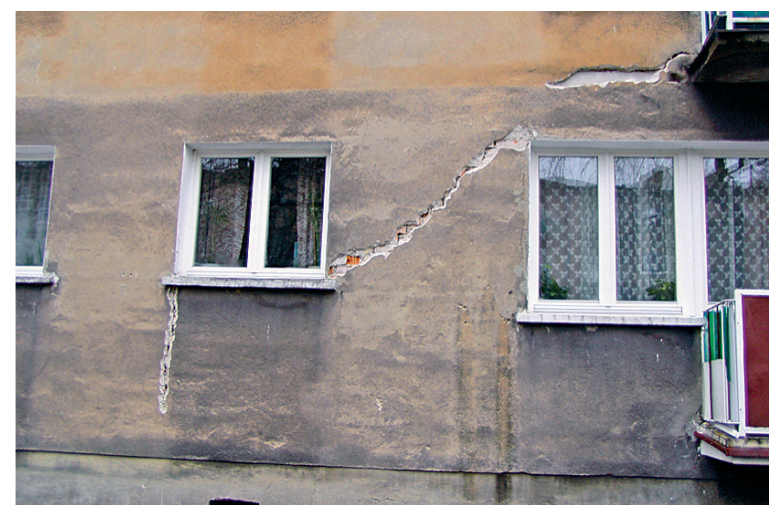

Fot. 1. Stan techniczny ścian zewnętrznych - zarysowania w narożniku klatki 46

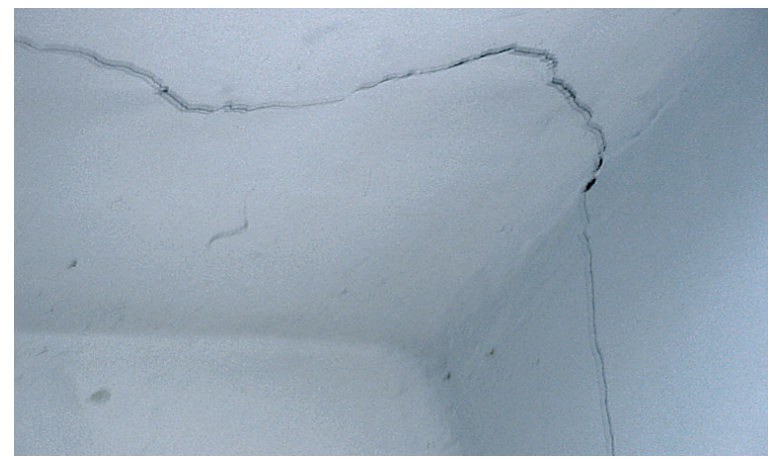

Fot. 2. Stan techniczny konstrukcji klatki schodowej. Widoczne pęknięcia ścian i spoczników klatki schodowej

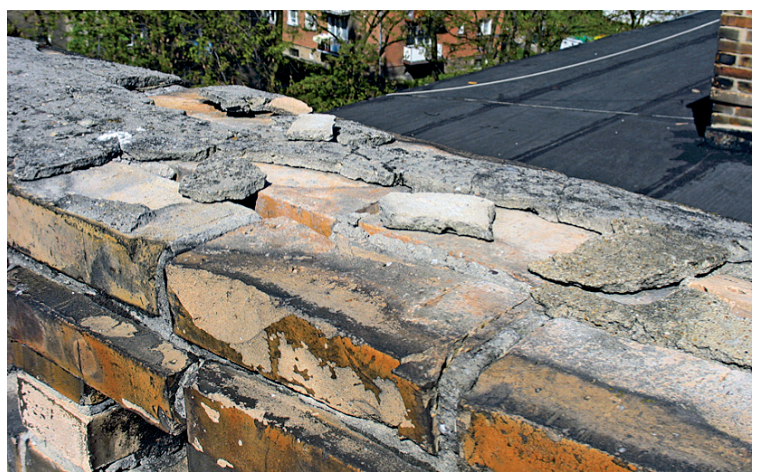

Fot. 3. Stan techniczny kominów 


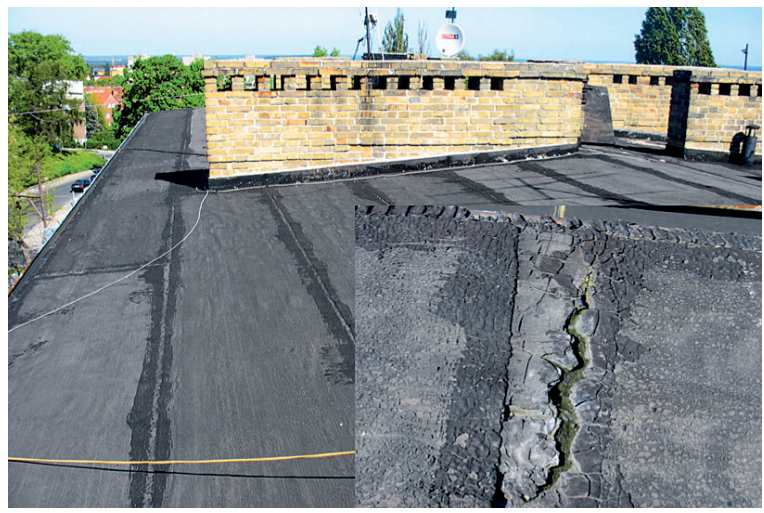

Fot. 4. Stan techniczny pokrycia dachowego. Widoczne znaczne uszkodzenia pokrycia papowego

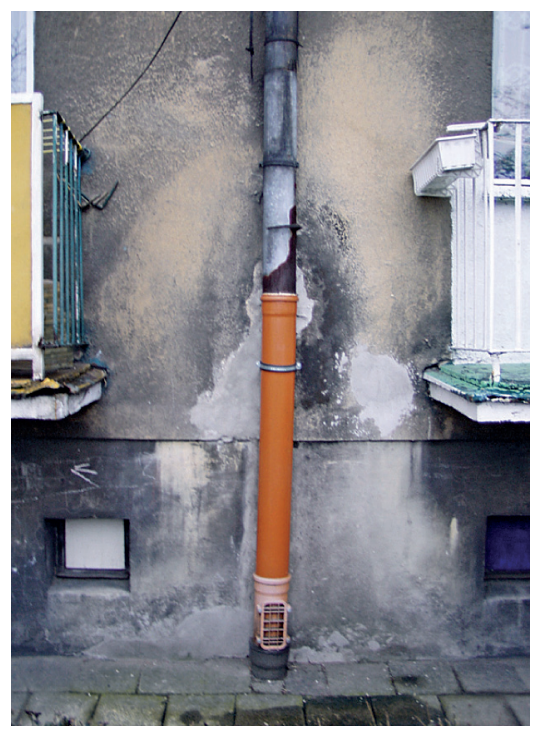

Fot. 5. Zawilgocenie ścian w rejonie rury spustowej między klatkami 44 i 46

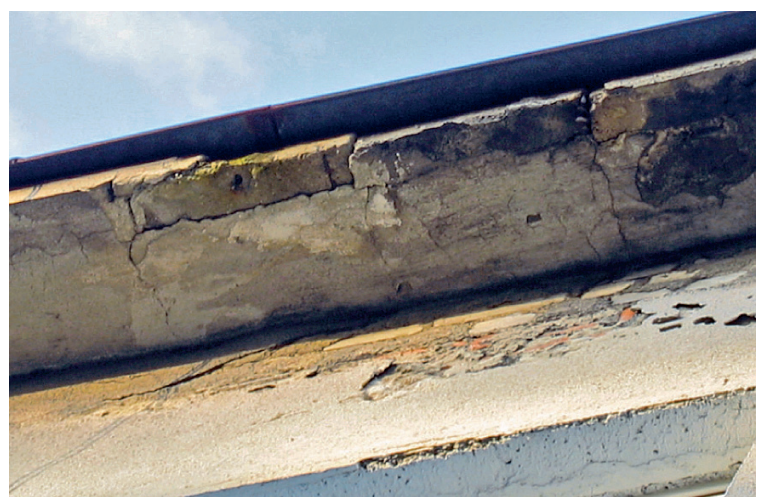

Fot. 6. Stan techniczny gzymsów dachowych 


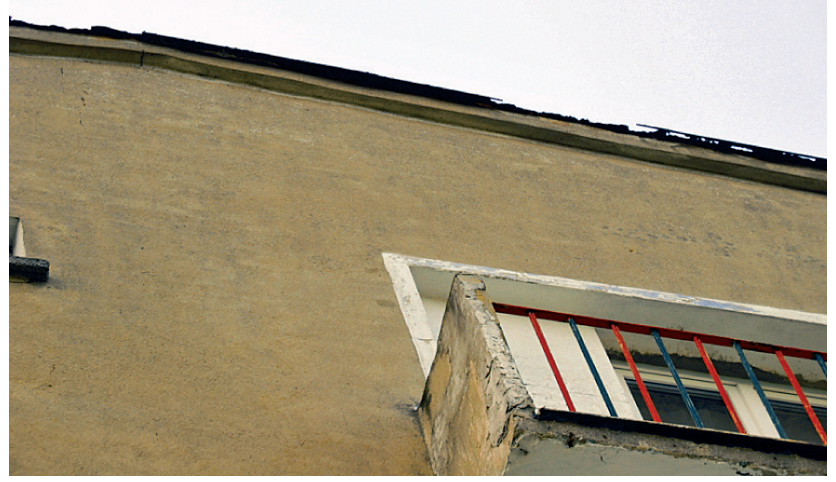

Fot. 7. Stan techniczny obróbek blacharskich

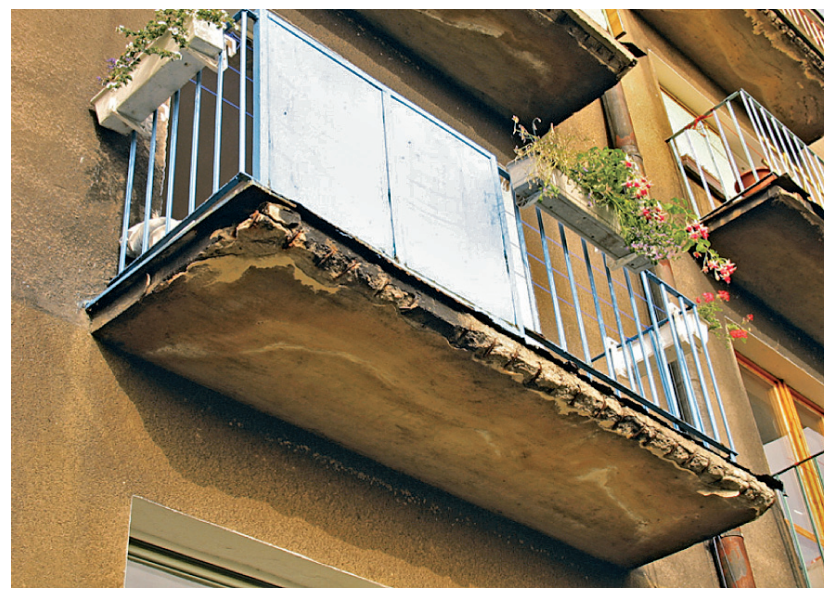

Fot. 8. Stan techniczny płyt balkonowych

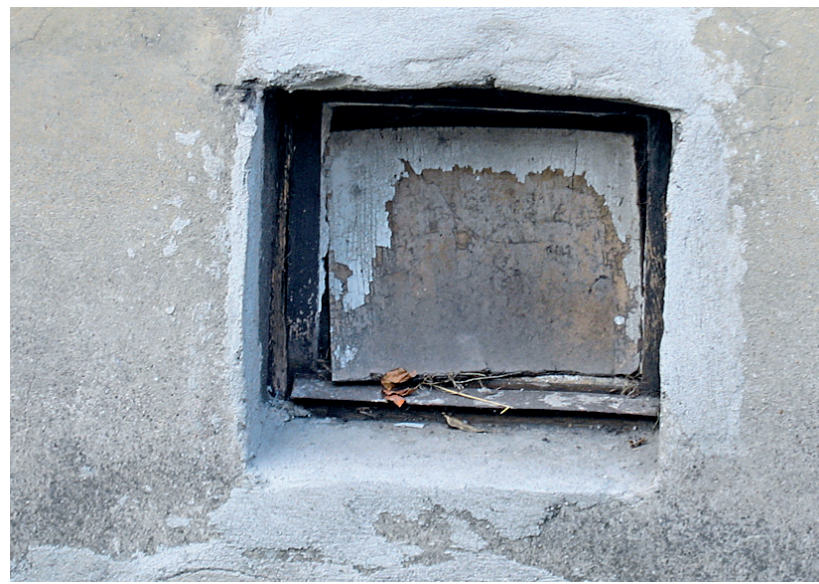

Fot. 9. Stan techniczny stolarki okiennej - brak oszklenia w otworach piwnic 


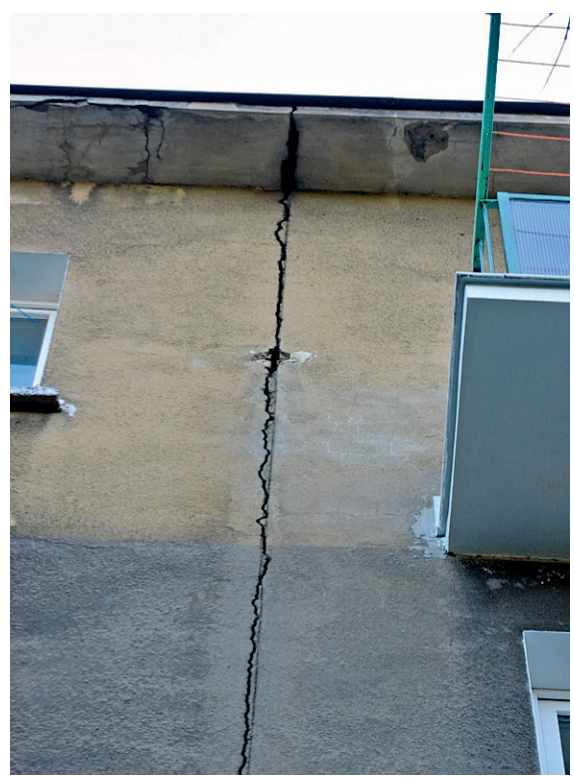

Fot. 10. Stan techniczny elewacji - dylatacja między klatkami 42-44

\section{Podsumowanie}

Przedstawiony w artykule przykład sporządzenia protokołu 5 - letniego oceny stanu technicznego budynku wskazuje jednoznacznie, że jakość wykonanego, w tym przypadku, przeglądu służy głównie spełnieniu wymogów wynikających z przepisów $[1,2,3]$, nie stanowi zaś dokumentu przydatnego do prawidłowego prowadzenia gospodarki remontowej. Przydatność wykonywanych okresowych przeglądów stanu technicznego budynków uzależniona jest przede wszystkim od rzetelności wykonanego opracowania przez osobę dokonującą przeglądu i jej świadomości w zakresie odpowiedzialności zawodowej, zarówno pod względem merytorycznym jak również w odniesieniu do obowiązujących przepisów.

Niezwykle istotnym wydaje się też weryfikacja opracowania przez zleceniodawcę i jego odpowiedzialność za stan techniczny obiektu jak i wiarygodność przed jego użytkownikami.

\section{Literatura}

[1] Ustawa z dnia 7 lipca 1994 r. Prawo budowlane (Dz. U. Nr 89, poz. 414- tekst jednolity z późniejszymi zmianami w 2004 r. Dz. U. Nr 6, poz. 41, Nr 92, poz. 881, Nr 93, poz. 888, Nr 96, poz. 959).

[2] Rozporządzenie Rady Ministrów z dnia 12 kwietnia 2002 r. w sprawie warunków technicznych jakim powinny odpowiadać budynki i ich usytuowanie (Dz. U. Nr 75, poz. 690)

[3] Rozporządzenie Rady Ministrów z dnia 16 sierpnia 1999 r. w sprawie warunków technicznych użytkowania budynków mieszkalnych (Dz. U. Nr 74, poz. 836).

[4] Przeglądy stanu technicznego budynków mieszkalnych wykonane dla zarządców budynków w Zielonej Górze w latach 2001-2007. 


\title{
Requirements for inspections of technical condition of buildings - case study
}

\author{
Krystyna Urbańska ${ }^{1}$, Pawel Urbański² \\ ${ }^{1}$ Department of Building Mechanics, Faculty of Civil Engineering, \\ Architecture and Environmental Engineering, University of Zielona Góra, \\ e-mail:k.urbanska@ib.uz.zgora.pl \\ ${ }^{2}$ Department of Building Technology, Geotechnics and Geodesy, Faculty of Civil Engineering, \\ Architecture and Environmental Engineering, University of Zielona Góra, \\ e-mail:p.urbanski@ib.uz.zgora.pl
}

\begin{abstract}
The aim of the article is to draw attention on periodic inspections concerning technical condition of buildings and signal the need for constant checking the content of received descriptions. Particulary in case of significant quantity errand prepared on one term. Rating of reliability drawn up periodical inspections of technical conditions was made on the example of multi-family buildings located in Zielona Góra.
\end{abstract}

Keywords: reviews of technical condition of buildings, planning of renovations. 